\title{
TP53BP1 wt Allele
}

National Cancer Institute

\section{Source}

National Cancer Institute. TP53BP1 wt Allele. NCI Thesaurus. Code C88926.

Human TP53BP1 wild-type allele is located within 15q15-q21 and is approximately $103 \mathrm{~kb}$ in length. This allele, which encodes tumor suppressor p53-binding protein 1, may be involved in the regulation of both mitosis and nonhomologous end joining after DNA damage. 